\title{
Effects of carbohydrate type or bicarbonate addition to grass silage-based diets on enteric methane emissions and milk fatty acid composition in dairy cows
}

\author{
A. Bougouin, A. Ferlay, M. Doreau, and C. Martin ${ }^{1}$ \\ INRA, UMR1213 Herbivores, F-63122 Saint-Genès-Champanelle, France; Clermont Université, VetAgro Sup, UMR Herbivores, BP10448, \\ F-63000 Clermont-Ferrand, France
}

\begin{abstract}
The aim of the study was to compare the effect of fiber- or starch-rich diets based on grass silage, supplemented or not with bicarbonate, on $\mathrm{CH}_{4}$ emissions and milk fatty acid (FA) profile in dairy cows. The experiment was conducted as a $4 \times 4$ Latin square design with a $2 \times 2$ factorial arrangement: carbohydrate type [starch- or fiber-rich diets with dietary starch level of 23.1 and $5.9 \%$ on a dry matter basis, respectively], without or with bicarbonate addition $[0$ and $1 \%$ of the dry matter intake, respectively]. Four multiparous lactating Holstein cows were fed 4 diets with $42 \%$ grass silage, $8 \%$ hay, and $50 \%$ concentrate in 4 consecutive 4-wk periods: (1) starch-rich diet, (2) starch-rich diet with bicarbonate, (3) fiber-rich diet, and (4) fiber-rich diet with bicarbonate. Intake and milk production were measured daily and milk composition was measured weekly; $\mathrm{CH}_{4}$ emission and total-tract digestibility were measured simultaneously ( $5 \mathrm{~d}$, wk 4 ) when animals were in open-circuit respiration chambers. Sensors continuously monitored rumen $\mathrm{pH}$ (3 d, wk 4), and fermentation parameters were analyzed from rumen fluid samples taken before feeding ( $1 \mathrm{~d}$, wk 3 ). Cows fed starch-rich diets had less $\mathrm{CH}_{4}$ emissions (on average, $-18 \%$ in $\mathrm{g} / \mathrm{d} ;-15 \%$ in $\mathrm{g} / \mathrm{kg}$ of dry matter intake; $-19 \%$ in $\mathrm{g} / \mathrm{kg}$ of milk) compared with fiber-rich diets. Carbohydrate type did not affect digestion of nutrients, except starch, which increased with starch-rich diets. The decrease in rumen protozoa number $(-36 \%)$ and the shift in rumen fermentation toward propionate at the expense of butyrate for cows fed the starch-rich diets may be the main factor in reducing $\mathrm{CH}_{4}$ emissions. Milk of cows fed starch-rich diets had lower concentrations in trans-11 C18:1, sum of cis-C18, cis-9,trans-11 conju-
\end{abstract}

Received October 24, 2017.

Accepted March 10, 2018.

${ }^{1}$ Corresponding author: cecile.martin@inra.fr gated linoleic acid (CLA), and sum of CLA, along with greater concentration of some minor isomers of CLA and saturated FA in comparison to the fiber-rich diet. Bicarbonate addition did not influence $\mathrm{CH}_{4}$ emissions or nutrient digestibility regardless of the carbohydrate type in the diet. Rumen $\mathrm{pH}$ increased with bicarbonate addition, whereas other rumen parameters and milk FA composition were almost comparable between diets. Feeding dairy cows a starch-rich diet based on grass silage helps to limit the negative environmental effect of ruminants, but does not lead to greater milk nutritional value because milk saturated FA content is increased.

Key words: bicarbonate, carbohydrate type, dairy cow, methane emission, milk fatty acid

\section{INTRODUCTION}

Livestock farming is a great contributor to total greenhouse gas emissions via $\mathrm{CH}_{4}$ production by cattle. Dairy cow $\mathrm{CH}_{4}$ emissions account for $46 \%$ of the total greenhouse gas emissions in dairy supply chains, when expressed as $\mathrm{CO}_{2}$-equivalents (Gerber et al., 2013), and also lead to significant energy losses ranging between 2 to $12 \%$ of the gross energy (GE) intake by animals (Johnson and Johnson, 1995). Livestock competitiveness needs to reduce enteric $\mathrm{CH}_{4}$ emissions without altering animal performance to improve feed efficiency and to reduce the carbon footprint of the dairy cattle sector.

Among the different dietary strategies tested worldwide, increasing the proportion of concentrate to above 30 to $40 \%$ in the diet is known to mitigate $\mathrm{CH}_{4}$ emissions in ruminants (Martin et al., 2010). Limited information is available on the effect of carbohydrate type in the diet on methanogenesis, though Hindrichsen et al. (2005) studied the effects of concentrates (50\% of the diet) providing different carbohydrates type on enteric $\mathrm{CH}_{4}$ emissions in dairy cows. These authors reported similar $\mathrm{CH}_{4}$ emissions (g/d and $\mathrm{g} / \mathrm{kg}$ of DMI) with fiber-rich concentrate (containing soybean hulls) as compared with starch-rich concentrate (containing wheat). 
Moe and Tyrrell (1979) reported that $\mathrm{CH}_{4}$ production in dairy cows is reduced further as the carbohydrate digestion rate is high. In addition, diets rich in readily fermentable carbohydrates such as starch are known to modify the rumen environment greatly through a decrease in $\mathrm{pH}$ and, consequently, to increase the risk of SARA (Krause and Oetzel, 2006). To limit these rumen disorders associated with high-starch diets, fiber can replace starch in carbohydrate diets because it is fermented more slowly, or sodium bicarbonate can be added to diets as a digestive regulator to reduce the risk of SARA (Solorzano et al., 1989). To the best of our knowledge, the effect of buffer addition to the diet of dairy cows on methanogenesis has been studied by very few authors. Hellwing et al. (2012) reported no effect of bicarbonate addition $(9.5 \mathrm{~g} / \mathrm{kg}$ of $\mathrm{DM})$ to a grass-clover silage-based diet rich in molasses on $\mathrm{CH}_{4}$ emissions ( $\mathrm{g} / \mathrm{d}$ and $\mathrm{g} / \mathrm{kg}$ of $\mathrm{DMI})$ in dairy cows when compared with a diet rich in wheat.

In addition to $\mathrm{CH}_{4}$ mitigation, high-starch diets may decrease milk fat content and modify milk fatty acid (FA) composition in dairy cows (Cabrita et al., 2007; Shingfield et al., 2008). Such diets may influence rumen biohydrogenation (RBH) of PUFA (Bauman and Griinari, 2003), resulting in a shift from the trans-11 C18:1 to the trans-10 C18:1 pathway. High-starch diets also modify the activity or number of bacteria implicated in the synthesis of odd- and branched-chain FA (Vlaeminck et al., 2006; Pirondini et al., 2015). Nevertheless, to the best of our knowledge, no authors have studied the effect of carbohydrate type on milk FA composition in dairy cows fed grass silage-based diets.

The aim with the study was to test the effects of (1) the carbohydrate type in diets [fiber-rich diets $(\mathbf{F})$ or starch-rich diets $(\mathbf{S})],(2)$ the addition of bicarbonate to diets, and (3) the interaction between the carbohydrate type and bicarbonate addition on digestive process, more particularly on $\mathrm{CH}_{4}$ emissions, and on milk FA composition in lactating dairy cows fed grass silagebased diets.

\section{MATERIALS AND METHODS}

The experiment was conducted at the animal experimental facilities of INRA Theix (Saint-Genès-Champanelle, France) from February to June 2015. Procedures involving animals were performed in accordance with the French Ministry of Agriculture guidelines for animal research and the applicable European Union guidelines and regulations on animal experiments. The Auvergne Regional Ethics Committee on Animal Experimentation C2EA-02 approved the experiment with the reference number 821-2015060811534198.

\section{Cows, Diets, and Experimental Design}

Four multiparous lactating Holstein cows (mean \pm $\mathrm{SD}$, average BW of $639 \pm 62 \mathrm{~kg}$, DIM of $61 \pm 12.5$, lactation rank of $2.8 \pm 0.4$, and milk yield of $31.5 \pm$ $4.6 \mathrm{~kg} / \mathrm{d}$ at the start of the experiment) were used in the experiment which was conducted as a $4 \times 4$ Latin square design with a $2 \times 2$ factorial arrangement. Each experimental period lasted $4 \mathrm{wk}(28 \mathrm{~d})$. From d 1 to 20 , cows were housed together in a free-stall barn and received the experimental ad libitum concentrates and forages. From d 21 to 26, cows were moved to individual open-circuit respiration chambers for measurement of $\mathrm{CH}_{4}$ emissions and total-tract digestibility, and were fed $95 \%$ of individual voluntary feed intake (determined during $\mathrm{d} 1$ to 20) to ensure complete consumption of the feed. Changes from one diet to another were achieved with 6 -d transition at the beginning of each 28 -d period. From d 27 to 28, cows returned to the freestall barn and were fed the same diet than from d 1 to 26 .

The 4 dietary treatments aimed at evaluating the main effects of the type of carbohydrates (fiber vs. starch), addition of bicarbonate, and their interaction and were (1) high-fiber diet (F), (2) high-fiber diet with bicarbonate addition $(\mathbf{F}+\mathbf{b})$, (3) high-starch diet (S), and (4) high-starch diet with bicarbonate addition $(\mathbf{S}+\mathbf{b})$. Diets contained a 50:50 forage-to-concentrate ratio, on a DM basis, $45 \%$ grass silage (natural grassland, first cut), $5 \%$ hay (natural grassland, first cut), and $50 \%$ pelleted concentrates and were formulated to meet individual energy and protein requirements for lactation and maintenance (INRA, 2007). In the F+b and $\mathrm{S}+\mathrm{b}$ diets, bicarbonate was weighed and mixed every day with the concentrate and given all together with the grass silage at the level of $1 \%$ of the DMI. The chemical composition of the different dietary ingredients and diets are reported in Table 1. Diets were iso-energy and iso-protein and were adjusted daily to maintain the forage-to-concentrate ratio as close as possible to the 50:50 ratio targeted. Hay was given once daily $(0730 \mathrm{~h})$; the grass silage and concentrates were mixed together by hand as a partial mixed ration (PMR) and were given twice a day $(66 \%$ at $0900 \mathrm{~h}$ and $34 \%$ at $1600 \mathrm{~h}$ ). Cows had free access to water throughout the experiment.

\section{Measurements, Sampling, and Chemical Analyses}

Feed Intake and Composition. Feed intake was weighted and recorded on $4 \mathrm{~d}$ in wk 1, 2, and 3 and on 5 $\mathrm{d}$ in wk 4 of each experimental period to estimate DMI as the difference between DM offered and refused. The $\mathrm{DM}$ content of feed was determined $\left(103^{\circ} \mathrm{C}\right.$ for $\left.24 \mathrm{~h}\right)$ 
Table 1. Chemical composition of the dietary ingredients and diets

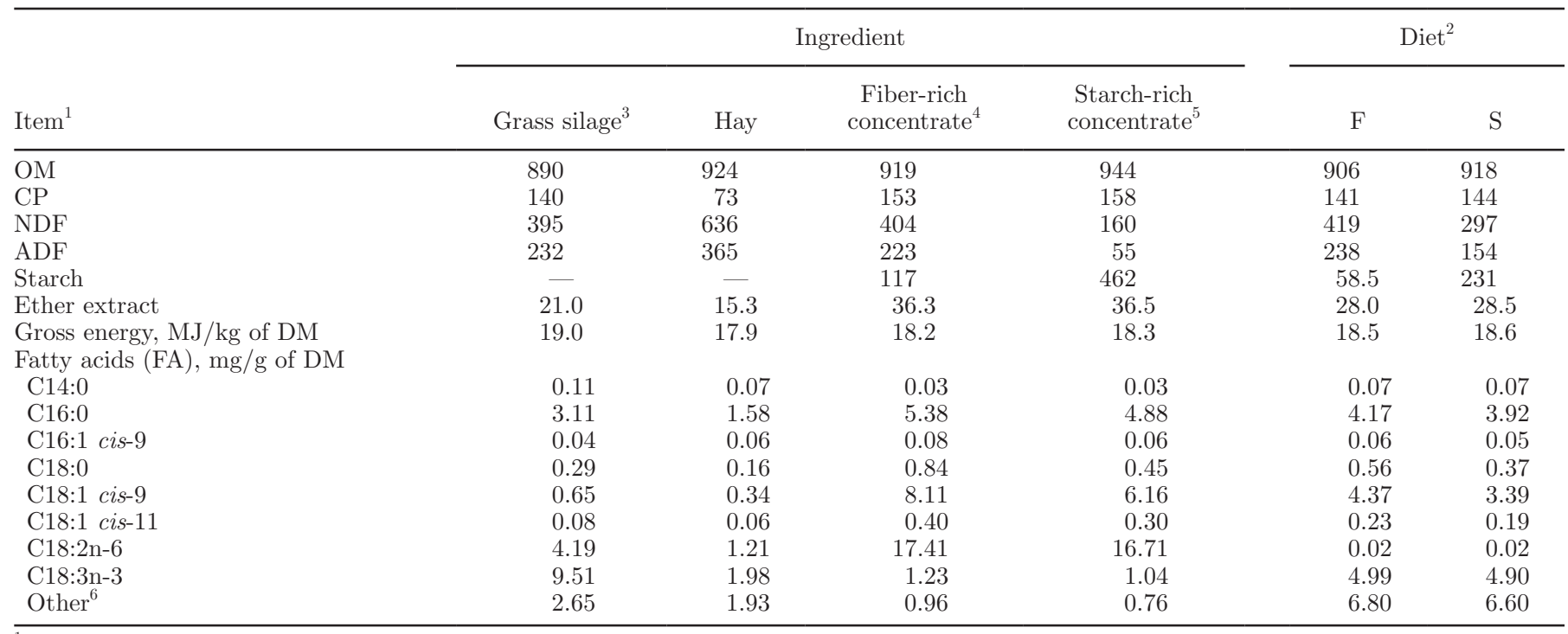

${ }^{1}$ Chemical composition expressed as grams per kilogram of DM unless stated otherwise.

${ }^{2} \mathrm{~F}=$ fiber-rich diets; $\mathrm{S}=$ starch-rich diets.

${ }^{3}$ Fermentation characteristics of fresh silage juice: $\mathrm{pH}=4.3$; lactic acid $=53.1 \mathrm{~g} / \mathrm{kg}$ of DM; $\mathrm{N}-\mathrm{NH}_{3}=8.0 \%$ of total $\mathrm{N}$.

${ }^{4}$ Composition (\% on DM basis) of the fiber-rich concentrate: beet pulp (22.3), soybean hull (22.2), distillers dried corn grains (15.5), wheat bran (10.9), corn grain (7.5), hay (5.4), corn gluten $60(0.9)$, molasses (1.5), and vitamins and minerals (3.6).

${ }^{5}$ Composition (\% on DM basis) of the starch-rich concentrate: wheat (30.1), corn grain (25.5), wheat middling (9.7), wheat starch (6.8), beet pulp (6.3), corn gluten 60 (4.8), molasses (1.5), and vitamins and minerals (4.2).

${ }^{6}$ Sum of all the other FA analyzed.

on samples (100 g) taken twice a week for grass silage and once a week for hay and concentrates (on wk 1, 2 , and 3 ), and for 5 consecutive days in wk 4 . If there were refusals in wk 4 , the DM content of each refused feedstuffs was measured $\left(103^{\circ} \mathrm{C}\right.$ for $\left.24 \mathrm{~h}\right)$. In addition, samples of each feedstuff $(100 \mathrm{~g})$ were taken twice in wk 4 , pooled to provide 1 sample per period, and stored at $4^{\circ} \mathrm{C}$ (concentrates, hay) or at $-20^{\circ} \mathrm{C}$ (grass silage). At the end of the experiment, all feedstuff samples were freeze-dried and ground (1-mm screen, ZM 200 Retsch Mill) for chemical composition determination (In Vivo Labs, Chierry, France) including fermentation parameters from fresh grass silage. Organic matter was determined by ashing at $550^{\circ} \mathrm{C}$ for $6 \mathrm{~h}$ (method 942.05; AOAC International, 2005). Total $\mathrm{N}$ was analyzed by combustion according to the Dumas method (method 968.06; AOAC International, 2005), and CP content was calculated as $\mathrm{N}$ content $\times 6.25$. Fiber $(\mathrm{NDF}$ and $\mathrm{ADF}$ ) was determined by sequential procedures (Van Soest et al., 1991) after pretreatment with amylase, and expressed exclusive of residual ash. Starch was analyzed using an enzymatic method (Faisant et al., 1995). Gross energy was analyzed by isoperibolic calorimetry (model C200, IKA, Staufen, Germany). Ether extract content was determined after acid hydrolysis (method 954.02; AOAC International, 2005). The $\mathrm{pH}$ of fresh grass si- lage juice as well as lactate, VFA, and ammonia-N concentrations were determined as described in Guyader et al. (2016). Fatty acid profile was analyzed according to Sukhija and Palmquist (1988) in all samples for grass silage (1 sample per period) and in a pooled sample for hay and for concentrates for the whole experiment. Total lipids from each diet ingredient were extracted with chloroform:methanol (1:3) along with an internal standard (C23:0, tricosanoic acid). For each ingredient, lipids were methylated with methanolic $\mathrm{HCl}$ and each individual FA amount and concentration was determined relative to the response factors for a known amount of the internal standard. Because refusals were negligible $(<1 \%$, data not shown), chemical composition of refusals was considered similar to that of the composition of the diet offered.

Digestibility. Total feces and urine collection was performed in individual boxes for 5 consecutive days on wk 4 when cows were housed in the open-circuit respiration chambers. Each morning, after weighing and mixing of feces and urine, one aliquot (1\%) was used for $\mathrm{DM}$ determination $\left(103^{\circ} \mathrm{C}\right.$ for $\left.24 \mathrm{~h}\right)$ and another aliquot $(0.5 \%)$ was pooled per week and per animal before being frozen $\left(-20^{\circ} \mathrm{C}\right)$. At the end of the experiment, samples were thawed, freeze-dried, and ground (1-mm screen, ZM 200 Retsch mill) for chemical composition 
determination of DM, OM, NDF, ADF, starch, and GE as previously described.

Body Weight, Energy Balance, and Milk Production and Composition. Cows were weighted at the beginning of the experiment and on wk 3 for each period. The energy balance (EB) was calculated as the difference between the energy intake and the energy requirement for lactation and maintenance (INRA, 2007). Cows were milked twice daily at 0730 and $1530 \mathrm{~h}$, and milk yield was individually recorded at each milking. Milk samples $(30 \mathrm{~mL})$ were collected for each cow on d 22 to 24 (wk 4) before storage at $+4^{\circ} \mathrm{C}$ with Bronopol (2-2-nitropropane-1,3-diol) as a preservative for milk component analysis. Fat, protein, lactose, and urea nitrogen contents were determined using MilkoScan 4000 (Foss Electric A/S, Hillerod, Denmark; Lial, Aurillac, France). Fat- and proteincorrected milk yield was calculated according to Gerber et al. (2011). For milk FA composition, another individual milk sample $(3 \mathrm{~mL})$ was taken on d 24 (wk 4) and frozen $\left(-20^{\circ} \mathrm{C}\right)$ without preservative after each milking. All samples were freeze-dried and then composited per day based on am and pm milk yields. The milk FA composition was determined as described by Ferlay et al. (2013). The composition of FAME of CLA isomers in milk fat was analyzed according to Lerch et al. (2012), with some modifications. Briefly, the FAME of CLA isomers were determined using an HPLC system (Agilent, 1200 series) equipped with 3 silver-impregnated silica columns (ChromSpher 5 Lipids, $250 \times 4.6 \mathrm{~mm}, 5-\mu \mathrm{m}$ particle size; Chromoptic, Courtaboeuf, France) coupled in series. Methyl esters of CLA were separated under isocratic conditions at $22^{\circ} \mathrm{C}$ using $0.1 \%$ (vol/vol) acetonitrile in n-heptane at a flow rate of $1 \mathrm{~mL} / \mathrm{min}$ and monitoring effluent at 233 and $210 \mathrm{~nm}$. The CLA isomers were identified based on retention time comparisons with a mixture of authentic standards (O5632, Sigma-Aldrich, St.Quentin-Fallavier, France). Concentrations of CLA isomers were calculated from the proportionate peak area responses determined by HPLC and the sum of concentrations of trans-7,cis-9 CLA, trans-8,cis-10 CLA, and cis-9,trans-11 CLA [with the following minor CLA isomers also taken into account in the sum: trans-11,cis-13 CLA (coeluted with cis-9,cis-11), trans-11,trans-13 CLA, trans-10,trans-12 CLA, trans9,trans-11 CLA, and trans-8,trans-10 CLA] weight percentage determined by $\mathrm{GC}$ analysis.

Methane Emissions. Cows were housed in opencircuit respiration chambers $\left(16.6 \mathrm{~m}^{3}\right.$ each) from d 21 $(0730 \mathrm{~h})$ to $\mathrm{d} 26(0730 \mathrm{~h})$ in wk 4 , during which the total $\mathrm{CH}_{4}$ emissions of each cow were measured continuously. The design and associated analytical equipment of the open-circuit respiration chambers are detailed in Guyader et al. (2015). Open-circuit respiration chambers operated at a slight negative pressure, with an airflow of $421 \pm 12 \mathrm{~m}^{3} / \mathrm{h}$ on average (approximately 45 air changes per $\mathrm{h}$ ). The open-circuit respiration chambers was flushed with ambient air for $3 \mathrm{~d}$ before each measurement period.

The front and rear doors were never opened simultaneously to avoid an air stream into the open-circuit respiration chambers. Rear doors were opened twice daily: in the morning for milking and to remove recovery boxes for feces and urine collection, and in the afternoon for milking. When the rear doors were closed, the front doors were opened for morning feeding (0830 $\mathrm{h}$ for hay and $0900 \mathrm{~h}$ for the PMR) and afternoon feeding (1600 $\mathrm{h}$ for the PMR). Missing data were estimated as being similar to the last measurement data before open-circuit respiration chambers disturbance. Methane emissions were calculated as the difference between open-circuit respiration chambers and ambient $\mathrm{CH}_{4}$ concentrations multiplied by the airflow corrected for environmental parameters (temperature, relative humidity, and pressure) according to Pinares-Patiño et al. (2012).

Plasma Parameters, Rumen pH, and Fermentation Parameters. Blood samples were collected from the coccygeal vein using tubes containing EDTA $(2.1 \mathrm{mg} / \mathrm{mL})$ after morning milking and before feeding on d 18 (wk 3). Blood samples were kept on ice after sampling and plasma was separated within $1 \mathrm{~h}$, by centrifugation at $1,700 \times g$ for $20 \mathrm{~min}$ at $4^{\circ} \mathrm{C}$, and frozen at $-20^{\circ} \mathrm{C}$ until it was analyzed for nonesterified FA (NEFA), BHB, acetate (C2), and glucose concentrations. Plasma NEFA, glucose, and acetate concentrations were determined by spectrophotometry using glucose dehydrogenase (Glucose RTU kit; BioMérieux, Lyon, France), acyl-CoA synthetase (Wako NEFA HR2 kit, Oxoid, Dardilly, France), and L-malate dehydrogenasecitrate synthase-acyl-CoA synthetase methods (Enzyplus EZA 811 + kit, Biocontrol Systems, Lyon, France), respectively. The BHB concentration was determined as described by Brashear and Cook (1983).

Rumen $\mathrm{pH}$ was monitored continuously using a commercial sensor (eBolus, eCow, Exeter, UK) over $3 \mathrm{~d}$ in wk 4 when animals were in open-circuit respiration chambers. At the start of the experiment, 1 calibrated sensor per cow was introduced permanently in the rumen through the esophagus by using a dedicated balling gun. Each sensor was set up to record mean $\mathrm{pH}$ over $15 \mathrm{~min}$ (96 data points per day) with an accuracy of \pm 0.1 . Data were downloaded every $15 \mathrm{~d}$ using an eCow handset (smartphone + antenna) with an eCow Android application. 
Rumen fluid samples (500 mL) were collected by stomach tubing (Shen et al., 2012) before the morning feeding on d 18 (wk 3) of each experimental period. Samples were strained through a polyester monofilament fabric $(250 \mu \mathrm{m}$ pore size) and the filtrate was subsampled for VFA concentration and protozoa counting. For VFA, $0.8 \mathrm{~mL}$ of filtrate was mixed for $2 \mathrm{~h}$ at $4^{\circ} \mathrm{C}$ with $0.5 \mathrm{~mL}$ of a $0.5 \mathrm{M} \mathrm{HCl}$ solution containing $2 \%$ (wt/vol) metaphosphoric acid and $0.4 \%$ (wt/vol), and then stored at $-20^{\circ} \mathrm{C}$. The VFA concentration was analyzed by GC with a flame ionization detector (Morgavi et al., 2008). For protozoa counting, 1-mL aliquot of rumen filtrate was mixed with $1 \mathrm{~mL}$ of methyl green formalin-saline solution, and stored at room temperature in darkness. Protozoa counts were done by microscopy and categorized as either small $(<100 \mu \mathrm{m})$ or large $(>100 \mu \mathrm{m})$ entodiniomorphs, or as holotrichs (Dasytricha or Isotricha; Williams and Coleman, 1992). Data for protozoa were $\log _{10}$-transformed for statistical analysis.

\section{Statistical Analysis}

Data were analyzed using mixed effect models with the lme4 package (version 1.1-10) in R statistical software (version 0.98.1102, R Foundation for Statistical Computing, Vienna, Austria). Fixed effects of period, carbohydrate type (F and $\mathrm{F}+\mathrm{b}$ vs. $\mathrm{S}$ and $\mathrm{S}+\mathrm{b}$ ), bicarbonate addition $(\mathrm{F}+\mathrm{b}$ and $\mathrm{S}+\mathrm{b}$ vs. $\mathrm{F}$ and $\mathrm{S})$, and the random effect of cow were tested with the following model:

$$
\mathrm{Y}_{\mathrm{ijk}}=\mu+\mathrm{P}_{\mathrm{i}}+\mathrm{A}_{\mathrm{j}}+\mathrm{B}_{\mathrm{k}}+\mathrm{C}_{\mathrm{l}}+\left(\mathrm{C}_{\mathrm{l}} \times \mathrm{B}_{\mathrm{k}}\right)+\varepsilon_{\mathrm{ijk} \mathrm{l}},
$$

where $Y_{i j k}$ is the dependent variable, $\mu$ is the overall mean, $\mathrm{P}_{\mathrm{i}}$ is the period ( $\mathrm{i}=1$ to 4$), \mathrm{A}_{\mathrm{j}}$ is the animal $(\mathrm{j}=$ 1 to 4$), \mathrm{B}_{\mathrm{k}}$ is the bicarbonate addition ( $\mathrm{k}=1$ and 2$), \mathrm{C}_{\mathrm{l}}$ is the type of carbohydrate (l=1 and 2$), C_{l} \times B_{k}$ is the interaction between carbohydrate type and bicarbonate addition, and $\varepsilon_{\mathrm{ijkl}}$ is the random residual error.

Data measured for several days in wk 4 (intake, milk production and composition, $\mathrm{CH}_{4}$ emissions, rumen $\mathrm{pH}$, total-tract digestibility) were averaged before being included in the statistical analyses. In period 1, the cow fed the diet $\mathrm{S}$ was taken out of the experiment because of health problems. It was replaced by another cow, fed diet $\mathrm{S}+\mathrm{b}$ in period 1 , and was used for the following 3 periods. In addition, it was not possible to download the $\mathrm{pH}$ data for one cow during the experiment because the sensor was not responding.

Least squares means were reported with the pooled standard error of the mean derived from the model. Effects were considered significant at a probability of $P \leq 0.05$.

\section{RESULTS}

\section{Total DMI, Milk Production and Composition, and Plasma Metabolites}

Total DMI was significantly reduced for the starchrich compared with the fiber-rich diets $(-750 \mathrm{~g} ; P=$ 0.02 ) because of a reduced intake of grass silage and concentrates (Table 2). The type of carbohydrate had no effect on milk production and composition, as well as on feed efficiency, BW, and EB (Table 2). Plasma NEFA, glucose, and acetate concentrations were not influenced by the carbohydrate type (Table 3). However, plasma BHB concentration was reduced $(P<0.001)$ and urea concentration was greater $(P=0.003)$ for starch-rich diets than for fiber-rich diets, respectively.

Bicarbonate addition did not change total DMI, BW, $\mathrm{EB}$, milk yield, milk content and yields of fat, protein and lactose, milk urea content, and feed efficiency. Bicarbonate addition to both starch- and fiber-rich diets reduced plasma NEFA concentration $(P=0.03$; Table 3), whereas the other plasma metabolites were unchanged.

\section{Nutrients Intake and Diet Digestibility}

Intakes of OM did not differ among diets (Table 4). Due to the experimental design, fiber intake was greater (on average +2.9 and $+2.0 \mathrm{~kg} / \mathrm{d}$ for NDF and ADF, respectively; $P<0.01$ ), and starch intake was lesser (on average $-3.7 \mathrm{~kg} / \mathrm{d} ; P<0.01$ ) for fiber- than for starch-rich diets, respectively. Gross energy intake was also increased in the fiber-rich diet as compared with the starch-rich diets (on average $+12.4 \mathrm{MJ} / \mathrm{d} ; P$ $=0.03$ ). Bicarbonate addition had no effect on the different nutrient intakes for the $\mathrm{F}$ and $\mathrm{S}$ diets.

Total-tract apparent digestibility of $\mathrm{DM}$ and $\mathrm{OM}$ was significantly greater for the starch-rich than for the fiber-rich diets (on average +5.4 and $+5.0 \%$, respectively; $P<0.001$; Table 4 ). Fiber (NDF and ADF) digestibility did not differ among diets, whereas starch and GE digestibility was also greater for starch-rich than for fiber-rich diets (on average +2.7 and $+3.9 \%$, respectively; $P<0.01$ ). Bicarbonate addition did not change total-tract diet digestibility of nutrients for $\mathrm{F}$ and $\mathrm{S}$ diets.

\section{Methane Emissions}

The carbohydrate type affected $\mathrm{CH}_{4}$ emissions (Table 5). Compared with fiber- rich diets, $\mathrm{CH}_{4}$ emissions (g/d) decreased by $-18 \%$ with starch-rich diets $(P=$ 0.007 ), by roughly $-15 \%$ when expressed per kilogram of DMI, $\mathrm{kg}$ of OM intake, or \% of GE intake $(P=0.02)$. 
Table 2. Feed intake, milk yield, and composition in dairy cows fed diets containing concentrates rich in fiber or starch, with or without bicarbonate addition

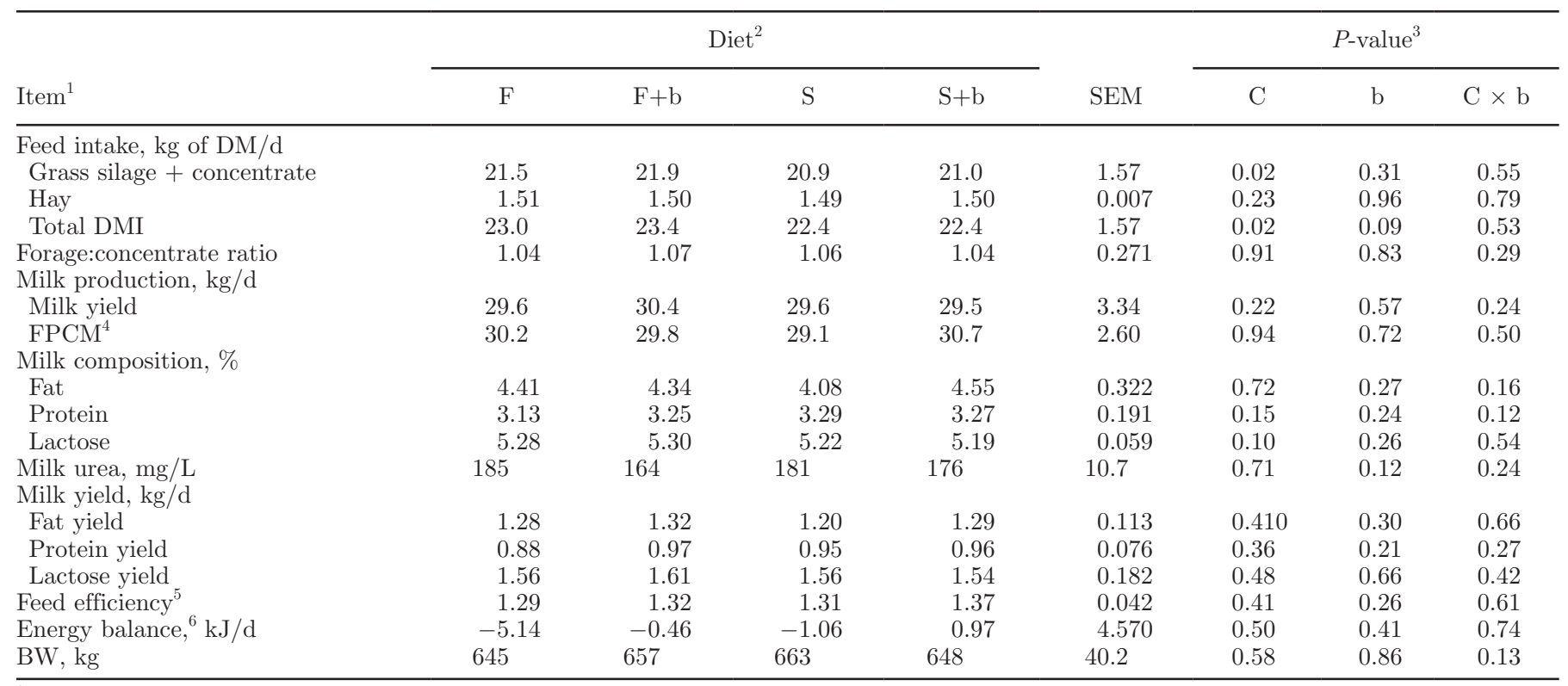

${ }^{1}$ Means of measurements on wk 4: $5 \mathrm{~d}$ for feed intake and milk production and $3 \mathrm{~d}$ for milk composition.

${ }^{2} \mathrm{~F}=$ diet rich in fiber; $\mathrm{S}=$ diet rich in starch; $\mathrm{F}+\mathrm{b}$ and $\mathrm{S}+\mathrm{b}=\mathrm{F}$ and $\mathrm{S}$ diets supplemented with bicarbonate at $1 \%$ of DMI.

${ }^{3} \mathrm{C}=$ carbohydrate type effect $(\mathrm{F}$ and $\mathrm{F}+\mathrm{b}$ vs. $\mathrm{S}$ and $\mathrm{S}+\mathrm{b}) ; \mathrm{b}=$ bicarbonate supplementation effect $(\mathrm{F}$ and $\mathrm{S}$ vs. $\mathrm{F}+\mathrm{b}$ and $\mathrm{S}+\mathrm{b})$, and their interaction $(\mathrm{C} \times \mathrm{b})$.

${ }^{4} \mathrm{FPCM}$, fat- and protein-corrected milk $=$ milk yield $(\mathrm{kg} / \mathrm{d}) \times[0.337+0.116 \times$ fat $(\%)+0.06 \times$ protein $(\%)]$ according to Gerber et al. $(2011)$. ${ }^{5}$ Feed efficiency $=$ FPCM $/$ DMI.

${ }^{6}$ Energy balance was estimated as the difference between energy intake and total energy requirements for lactation and maintenance (INRA, 2007).

Expressed per kilogram of NDF intake or kilogram of NDF digested, $\mathrm{CH}_{4}$ emissions were greater for starch than for fiber diets by $+19 \%(P<0.05)$. Emissions of $\mathrm{CH}_{4}$ per kilogram of milk were significantly reduced with starch-rich diets in comparison to fiber-rich diets $(-19 \%, P<0.001)$. Irrespective of the unit used, bicarbonate addition in the diets did not affect $\mathrm{CH}_{4}$ emissions in dairy cows.

\section{Rumen $\mathrm{pH}$ and Fermentation Parameters}

Mean rumen $\mathrm{pH}$ was not affected by the carbohydrate type, but minimum $\mathrm{pH}$ was reduced with starch-rich diets as compared with fiber-rich diets (on average -0.14 $\mathrm{pH}$ unit, $P<0.01$; Table 6$)$. Bicarbonate addition in $\mathrm{F}$ and $\mathrm{S}$ diets increased the mean $\mathrm{pH}(+0.14 \mathrm{pH}$ unit; $P$ $=0.006)$ and minimum $\mathrm{pH}(+0.06 \mathrm{pH}$ unit, $P \leq 0.05)$.

Table 3. Plasma metabolites concentration in dairy cows fed diets containing concentrates rich in fiber or starch, with or without bicarbonate addition

\begin{tabular}{|c|c|c|c|c|c|c|c|c|}
\hline Item $^{1}$ & \multicolumn{4}{|c|}{$\operatorname{Diet}^{2}$} & SEM & \multicolumn{3}{|c|}{$P$-value ${ }^{3}$} \\
\hline $\mathrm{BHB}, \mathrm{mmol} / \mathrm{L}$ & 0.72 & 0.74 & 0.51 & 0.42 & 0.042 & $<0.001$ & 0.26 & 0.12 \\
\hline Glucose, g/L & 0.72 & 0.71 & 0.74 & 0.74 & 0.024 & 0.23 & 0.96 & 0.73 \\
\hline Acetate, $\mathrm{mmol} / \mathrm{L}$ & 1.0 & 0.85 & 0.72 & 0.64 & 0.148 & 0.16 & 0.49 & 0.82 \\
\hline Urea, g/L & 0.13 & 0.14 & 0.18 & 0.17 & 0.016 & 0.003 & 0.76 & 0.22 \\
\hline
\end{tabular}

${ }^{1}$ Measurements taken on wk 3. NEFA = nonesterified fatty acids.

${ }^{2} \mathrm{~F}=$ diet rich in fiber; $\mathrm{S}=$ diet rich in starch; $\mathrm{F}+\mathrm{b}$ and $\mathrm{S}+\mathrm{b}=\mathrm{F}$ and $\mathrm{S}$ diets supplemented with bicarbonate at $1 \%$ of DMI.

${ }^{3} \mathrm{C}=$ carbohydrate type effect $(\mathrm{F}$ and $\mathrm{F}+\mathrm{b}$ vs. $\mathrm{S}$ and $\mathrm{S}+\mathrm{b}) ; \mathrm{b}=$ bicarbonate supplementation effect $(\mathrm{F}$ and $\mathrm{S}$ vs. $\mathrm{F}+\mathrm{b}$ and $\mathrm{S}+\mathrm{b})$, and their interaction $(\mathrm{C} \times \mathrm{b})$. 
Table 4. Daily nutrient intake and total-tract apparent digestibility in dairy cows fed diets containing concentrates rich in fiber or starch, with or without bicarbonate addition

\begin{tabular}{|c|c|c|c|c|c|c|c|c|}
\hline Item $^{1}$ & \multicolumn{4}{|c|}{ Diet $^{2}$} & SEM & \multicolumn{3}{|c|}{$P$-value ${ }^{3}$} \\
\hline $\mathrm{OM}$ & 20.9 & 21.2 & 20.6 & 20.7 & 1.43 & 0.12 & 0.32 & 0.61 \\
\hline $\mathrm{NDF}$ & 9.6 & 9.7 & 6.8 & 6.7 & 0.53 & $<0.001$ & 0.81 & 0.13 \\
\hline $\mathrm{ADF}$ & 5.4 & 5.5 & 3.6 & 3.5 & 0.30 & $<0.001$ & 0.97 & 0.15 \\
\hline Starch & 1.3 & 1.3 & 4.9 & 5.1 & 0.28 & $<0.001$ & 0.48 & 0.49 \\
\hline DM & 62.2 & 62.4 & 68.4 & 67.0 & 0.78 & $<0.001$ & 0.48 & 0.35 \\
\hline $\mathrm{OM}$ & 68.7 & 69.2 & 74.4 & 73.4 & 0.82 & $<0.001$ & 0.74 & 0.38 \\
\hline $\mathrm{NDF}$ & 63.5 & 62.7 & 61.6 & 61.7 & 1.37 & 0.31 & 0.81 & 0.76 \\
\hline $\mathrm{ADF}$ & 62.1 & 61.0 & 60.3 & 61.3 & 2.02 & 0.66 & 0.96 & 0.54 \\
\hline Starch & 95.7 & 95.3 & 98.1 & 98.2 & 0.42 & $<0.001$ & 0.68 & 0.51 \\
\hline Gross energy & 63.5 & 64.9 & 68.1 & 68.1 & 0.75 & 0.003 & 0.41 & 0.41 \\
\hline
\end{tabular}

${ }^{1}$ Average data of the 5 -d measurement period in wk 4 .

${ }^{2} \mathrm{~F}=$ diet rich in fiber; $\mathrm{S}=$ diet rich in starch; $\mathrm{F}+\mathrm{b}$ and $\mathrm{S}+\mathrm{b}=\mathrm{F}$ and $\mathrm{S}$ diets supplemented with bicarbonate at $1 \%$ of $\mathrm{DMI}$.

${ }^{3} \mathrm{C}=$ carbohydrate type effect $(\mathrm{F}$ and $\mathrm{F}+\mathrm{b}$ vs. $\mathrm{S}$ and $\mathrm{S}+\mathrm{b}) ; \mathrm{b}=$ bicarbonate supplementation effect $(\mathrm{F}$ and $\mathrm{S}$ vs. $\mathrm{F}+\mathrm{b}$ and $\mathrm{S}+\mathrm{b})$, and their interaction $(\mathrm{C} \times \mathrm{b})$.

Total VFA concentration was reduced with starchrich than with fiber-rich diets $(-13.5 \mathrm{mM} ; P=0.02$; Table 6). The proportion of C2 in total VFA was unaffected, whereas the proportions of propionate $(\mathbf{C 3})$ and valerate were increased $(P=0.003)$ and that of butyrate $(\mathbf{C} 4)$ was decreased $(P=0.002)$, as were $\mathrm{C} 2$ :C3 and $(\mathrm{C} 2+\mathrm{C} 4)$ :C3 ratios $(P<0.002)$, by starch- compared with fiber-rich diets. Bicarbonate addition increased the proportion of $\mathrm{C} 3$ in total VFA and decreased the $\mathrm{C} 2$ :C3 and $(\mathrm{C} 2+\mathrm{C} 4)$ :C3 ratios $(P \leq 0.05)$, whatever the diet.

Total protozoa concentration was on average 2.8 times greater for fiber-rich compared with starch-rich diets $(P=0.01$, Table 6$)$. Type of carbohydrate and bicarbonate addition did not modify the rumen concen- trations of the total and different species of protozoa, irrespective of diet.

\section{Milk Fatty Acid Composition}

The starch-rich diets induced a greater concentration of SFA (72.1 vs. $67.6 \%$ of total FA for starch- and fiber-rich diets, respectively; Table $7, P \leq 0.05)$ and of short- and medium-chain FA (sum FA $<16 \mathrm{C}, 30.0$ vs. $26.1 \%$ of total FA for starch- and fiber-rich diets, respectively; Table $7, P \leq 0.05$ ) than with the fiber-rich diet. However, starch-rich diets induced less MUFA concentration as compared with fiber diets (21.3 vs. $25.5 \%$ of total FA, respectively; $P=0.03$ ). The C5:0, C6:0, C7:0, C8:0, C9:0, C10:0, C11:0, C12:0, C13:0, C14:0,

Table 5. Methane emissions in dairy cows fed diets containing concentrates rich in fiber or starch, with or without bicarbonate addition

\begin{tabular}{|c|c|c|c|c|c|c|c|c|}
\hline Item $^{1}$ & \multicolumn{4}{|c|}{ Diet $^{2}$} & SEM & \multicolumn{3}{|c|}{$P$-value ${ }^{3}$} \\
\hline $\mathrm{CH}_{4}, \mathrm{~g} / \mathrm{d}$ & 470 & 495 & 408 & 381 & 34.8 & 0.007 & 0.82 & 0.36 \\
\hline $\mathrm{CH}_{4}, \mathrm{~g} / \mathrm{kg}$ of $\mathrm{OM}$ intake & 23.0 & 23.5 & 20.1 & 18.8 & 1.68 & 0.01 & 0.73 & 0.44 \\
\hline $\mathrm{CH}_{4}, \mathrm{~g} / \mathrm{kg}$ of NDF intake & 50.2 & 51.3 & 61.8 & 58.6 & 4.99 & 0.04 & 0.76 & 0.55 \\
\hline $\mathrm{CH}_{4}, \%$ of gross energy intake & 6.2 & 6.3 & 5.5 & 5.2 & 0.46 & 0.02 & 0.63 & 0.45 \\
\hline $\mathrm{CH}_{4}, \mathrm{~g} / \mathrm{kg}$ of milk & 16.9 & 17.0 & 14.0 & 13.2 & 1.91 & $<0.001$ & 0.49 & 0.38 \\
\hline $\mathrm{CH}_{4}, \mathrm{~g} / \mathrm{kg}$ of $\mathrm{FPCM}$ & 16.4 & 18.7 & 14.2 & 12.7 & 2.08 & 0.06 & 0.83 & 0.31 \\
\hline
\end{tabular}

${ }^{1}$ Average data of 5 -d measurement period in wk 4 .

${ }^{2} \mathrm{~F}=$ diet rich in fiber; $\mathrm{S}=$ diet rich in starch; $\mathrm{F}+\mathrm{b}$ and $\mathrm{S}+\mathrm{b}=\mathrm{F}$ and $\mathrm{S}$ diets supplemented with bicarbonate at $1 \%$ of DMI.

${ }^{3} \mathrm{C}=$ carbohydrate type effect $(\mathrm{F}$ and $\mathrm{F}+\mathrm{b}$ vs. $\mathrm{S}$ and $\mathrm{S}+\mathrm{b}) ; \mathrm{b}=$ bicarbonate supplementation effect $(\mathrm{F}$ and $\mathrm{S}$ vs. $\mathrm{F}+\mathrm{b}$ and $\mathrm{S}+\mathrm{b})$, and their interaction $(\mathrm{C} \times \mathrm{b})$.

${ }^{4} \mathrm{FPCM}$, fat- and protein-corrected milk $=$ milk yield $(\mathrm{kg} / \mathrm{d}) \times[0.337+0.116 \times$ fat $(\%)+0.06 \times$ protein $(\%)]$ according to Gerber et al. $(2011)$. 
C15:0, C16:0, C17:0, cis-9 C12:1, cis-9 C14:1, trans-9 C14:1 concentrations were greater for starch-rich than for fiber-rich diets $(P \leq 0.05$; Table 7 and Supplemental Table S1; https://doi.org/10.3168/jds.2017-14041).

Cows fed starch-rich diets had less milk concentration of total C18 FA than those fed fiber-rich diets (31.0 vs. $37.2 \%$ of total FA, respectively; $P \leq 0.05$; Table 6 ), but greater concentration of several isomers of CLA (i.e., trans-10,trans-12, trans-7,cis-9 + trans-8,cis-10, and cis-11 trans-13; Table 8) and trans-9,cis-12 C18:2, cis-11 C18:1, and cis-13 C18:1 (Table 8). However, concentrations of the sum of cis isomers of $\mathrm{C} 18: 1$, cis9,trans-11 CLA, and the sum of CLA were reduced with starch-rich than with fiber-rich diets $(P \leq 0.05$; Table 8).

Bicarbonate addition had a slight effect on milk FA composition. Milk concentrations of C4:0, iso C18:0, and some isomers of CLA (trans-10,trans-12, trans-7,trans-9, and trans-12,cis-14) were reduced by bicarbonate addition, whereas milk concentrations of cis-9,trans-11 CLA, cis-9 20:1 ( $P \leq 0.05$; Table 8), total PUFA, and total CLA were increased $(P \leq 0.05$; Table 7).

\section{DISCUSSION}

\section{Methane Emissions and Other Digestive Processes}

Effect of Carbohydrate Type. In our study, cows fed the starch-rich diets had less $\mathrm{CH}_{4}$ emissions (on average, $-18 \%$ in $\mathrm{g} / \mathrm{d} ;-15 \%$ in $\mathrm{g} / \mathrm{kg}$ of DMI; $-14 \%$ in \% of GE intake) than fiber-rich diets. Using a modeling approach, Benchaar et al. (2001) also observed a $14 \%$ decrease in $\mathrm{CH}_{4}$ emissions (g/d) in cows when $10 \%$ NDF from beet pulp was replaced by starch from barley in a $70 \%$ alfalfa hay-based diet. To the best of our knowledge, very few authors have compared the concentrate carbohydrate type with grass silage baseddiet on $\mathrm{CH}_{4}$ emissions. Hindrichsen et al. (2005) studied the effects of concentrates ( $50 \%$ of the diet) containing different carbohydrates types on enteric $\mathrm{CH}_{4}$ emissions in dairy cows fed a mixture of forages $(22 \%$ corn silage, $45 \%$ grass silage, $33 \%$ hay on a DM basis). Contrary to our results, these authors did not report effect of the carbohydrate types on $\mathrm{CH}_{4}$ emissions $(\mathrm{g} / \mathrm{d}$ and $\mathrm{g} / \mathrm{kg}$ of DMI) between fiber-rich (containing soybean hulls) and starch-rich diets (containing wheat). However, less $\mathrm{CH}_{4}$

Table 6. Rumen $\mathrm{pH}^{1}$ and fermentation characteristics ${ }^{2}$ in dairy cows fed diets containing concentrates rich in fiber or starch, with or without bicarbonate addition

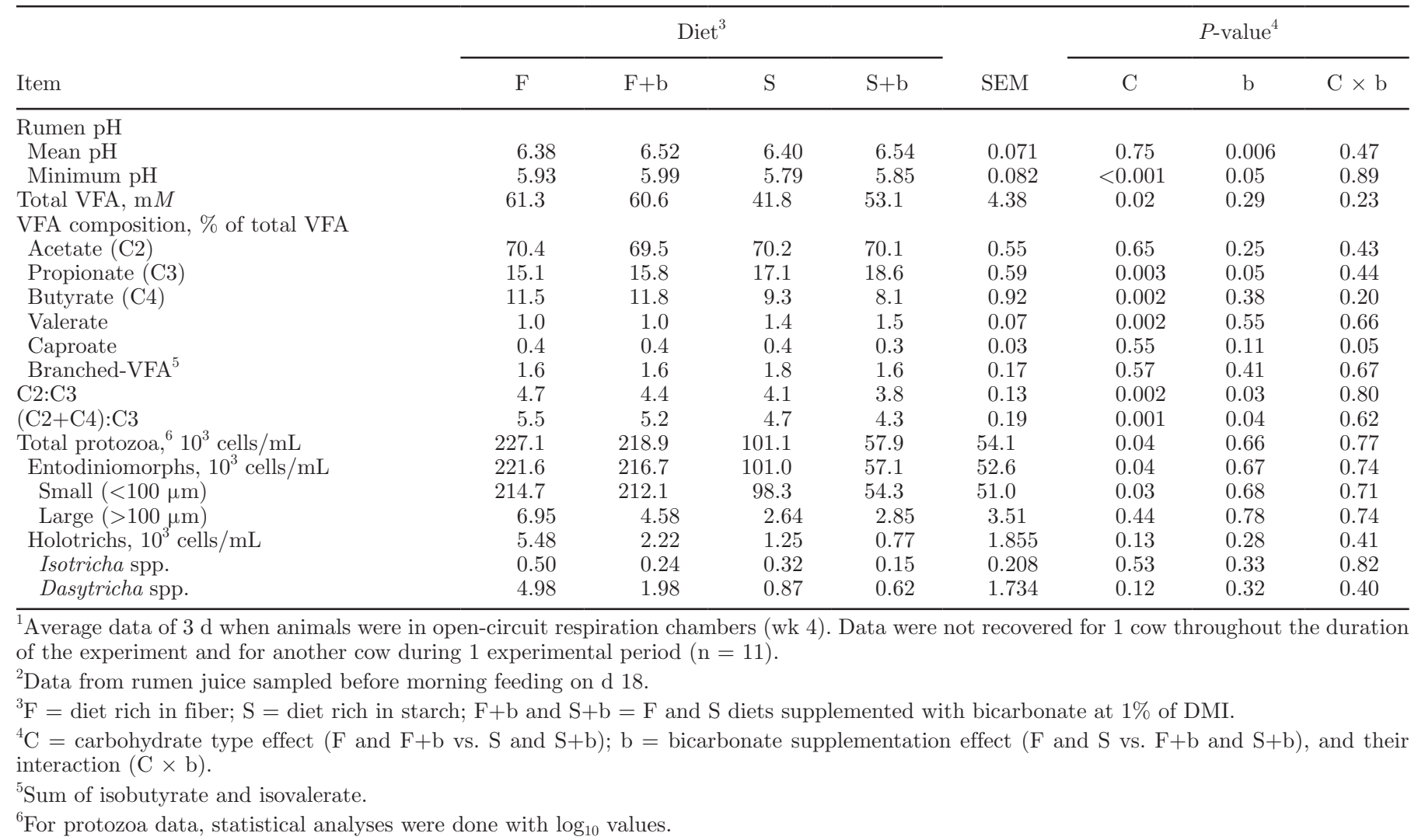


Table 7. Milk fatty acid (FA) composition ${ }^{1}$ in dairy cows fed diets containing concentrates rich in fiber or starch, with or without bicarbonate addition

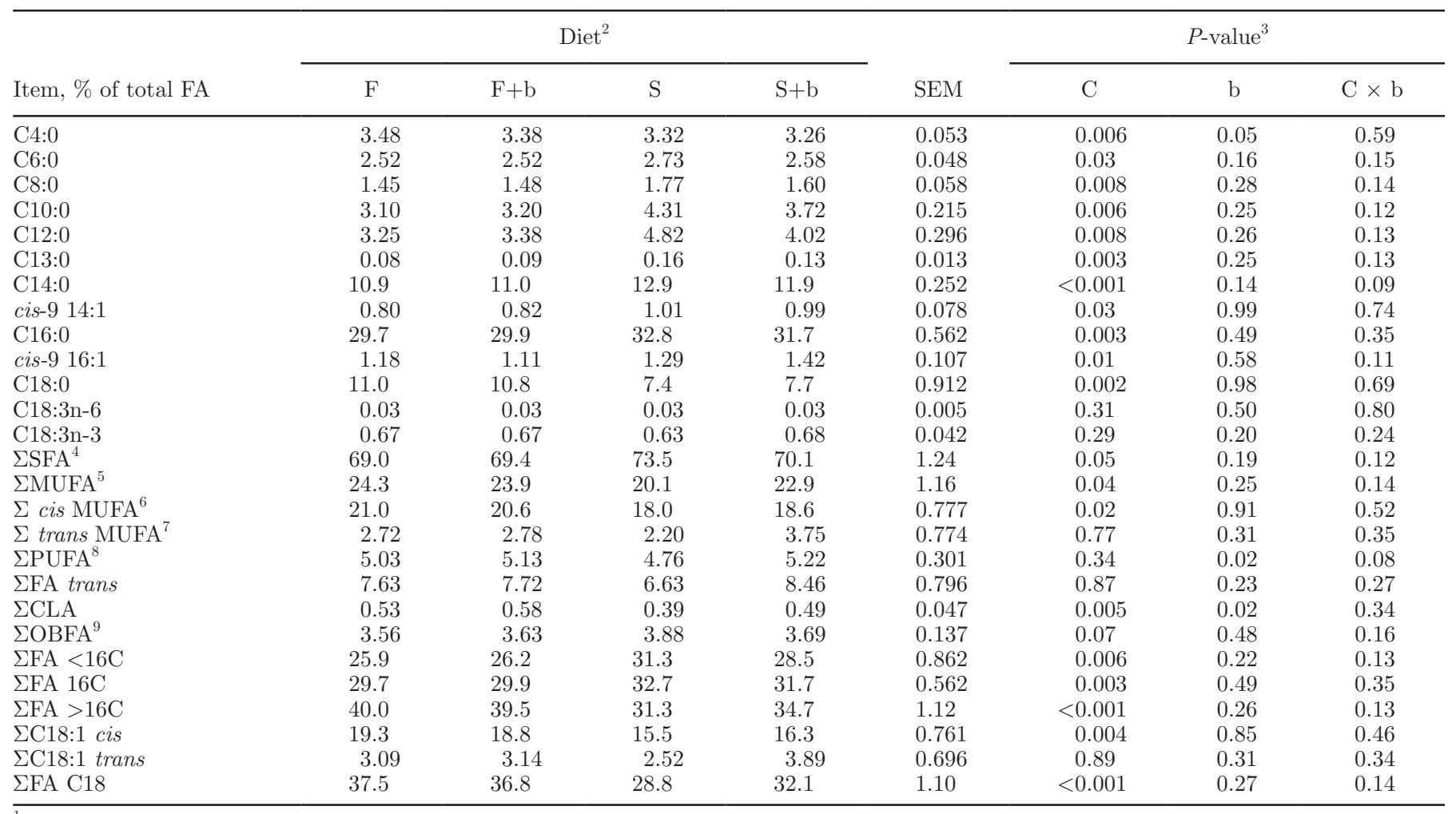

${ }^{1}$ Measurement taken on d 24 in wk 4 .

${ }^{2} \mathrm{~F}=$ diet rich in fiber; $\mathrm{S}=$ diet rich in starch, $\mathrm{F}+\mathrm{b}$ and $\mathrm{S}+\mathrm{b}=\mathrm{F}$ and $\mathrm{S}$ diets supplemented with bicarbonate at $1 \%$ of $\mathrm{DMI}$.

${ }^{3} \mathrm{C}=$ carbohydrate type effect $(\mathrm{F}$ and $\mathrm{F}+\mathrm{b}$ vs. $\mathrm{S}$ and $\mathrm{S}+\mathrm{b}) ; \mathrm{b}=$ bicarbonate supplementation effect $(\mathrm{F}$ and $\mathrm{S}$ vs. $\mathrm{F}+\mathrm{b}$ and $\mathrm{S}+\mathrm{b})$, and their interaction $(\mathrm{C} \times \mathrm{b})$.

${ }^{4}$ Sum SFA = odd-chain fatty acids + branched-chain fatty acids + even fatty acids, including fatty acids from 4 to 26 carbon atoms.

${ }^{5}$ Sum of MUFA from 10 to 22 carbon atoms.

${ }^{6} \mathrm{Sum}$ of MUFA from 10 to 22 carbon atoms with the cis configuration.

${ }^{7}$ Sum of MUFA from 10 to 22 carbon atoms with the trans configuration.

${ }^{8}$ Sum of PUFA from 18 to 26 carbon atoms.

${ }^{9} \mathrm{OBFA}=$ sum of odd-chain and branched-chain fatty acids.

emissions were measured for the fiber-rich diet when expressed per unit of NDF, which is in agreement with our results.

The observed $\mathrm{CH}_{4}$ abatement with starch-rich diets appears to be linked to pre-prandial modifications in rumen fermentation and microbial population. The reduced total VFA concentration in the rumen with starch-rich diets may be due to the more limited DMI. Carbohydrate type in diets also affected the rumen VFA profile, with greater $\mathrm{C} 3$ and reduced $\mathrm{C} 4$ proportions in starch-rich diets. It is well known that increasing starch level in the diet, at the expense of fiber carbohydrates (NDF and ADF), leads to a shift in rumen fermentation in favor of the propionate pathway (Bannink et al., 2006), creating an alternative $\mathrm{H}_{2}$ sink to methanogenesis (Martin et al., 2010).
The total count of protozoa, specifically entodinomorphs, was reduced for starch-rich than for fiber-rich diets, leading to less $\mathrm{C} 4$ proportion, as protozoa are C4 producers (Morgavi et al., 2012). Hassanat et al. (2013) also reported a decrease in protozoa population and in $\mathrm{C} 4$ proportion in the rumen of cows fed high-starch diets based on corn silage. In addition, the observed decrease in protozoa population may have led to a reduction of $\mathrm{H}_{2}$ transfer from protozoa to methanogens and consequently to reduced methanogenesis. A meta-analysis of 28 experiments and 91 treatments indicated a significant linear relationship between $\mathrm{CH}_{4}$ emissions and protozoa population $(\mathrm{r}=0.96)$ in the rumen (Guyader et al., 2014). Also, the reduced protozoa population with starch-rich diets led to faster bacterial rumen fermentation and a reduced minimum 
Table 8. Milk C18:1, C18:2, and CLA composition ${ }^{1}$ in dairy cows fed diets containing concentrates rich in fiber or starch, with or without bicarbonate addition

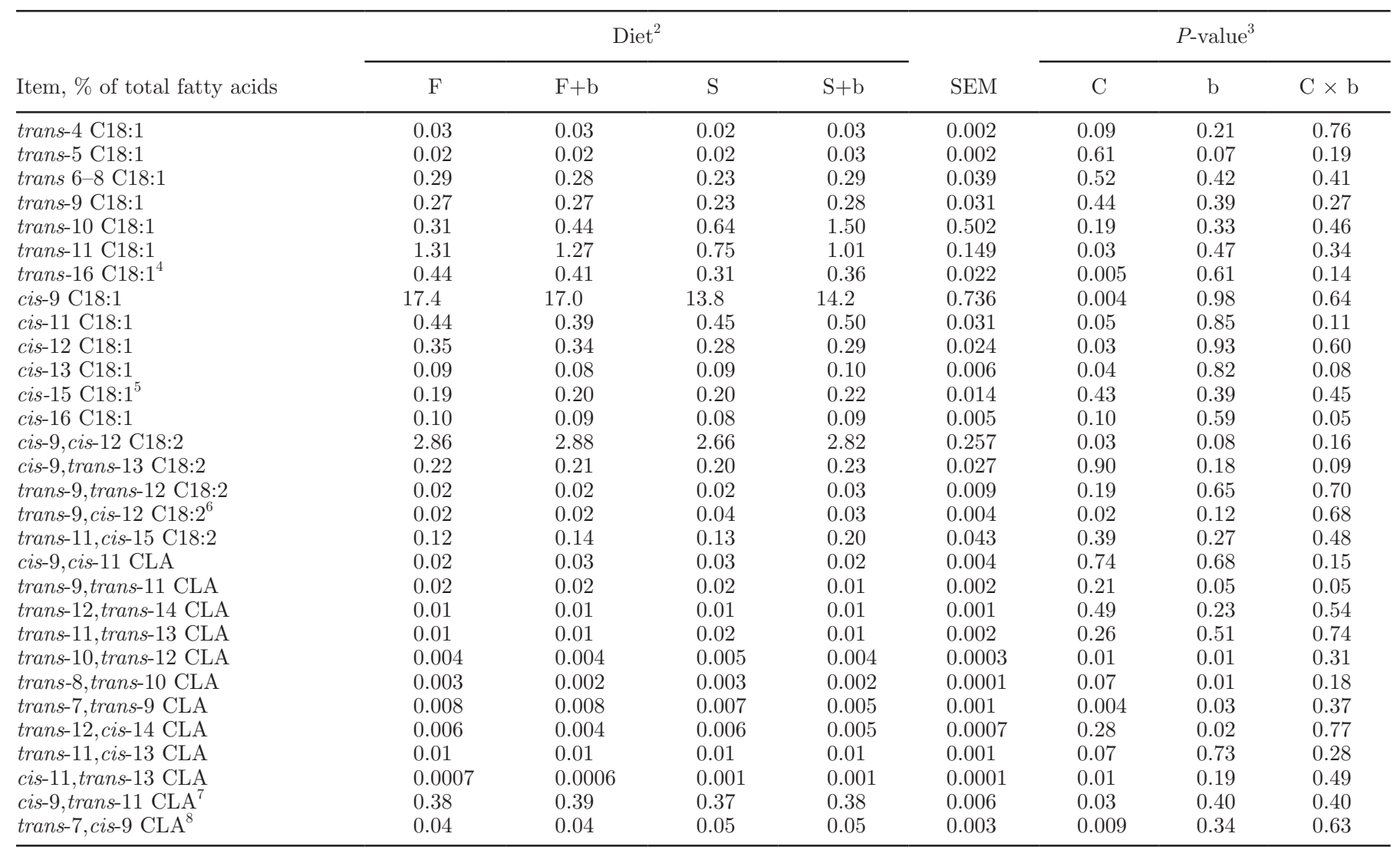

${ }^{1}$ Measurement taken on d 24 in wk 4.

${ }^{2} \mathrm{~F}=$ diet rich in fiber; $\mathrm{S}=$ diet rich in starch, $\mathrm{F}+\mathrm{b}$ and $\mathrm{S}+\mathrm{b}=\mathrm{F}$ and $\mathrm{S}$ diets supplemented with bicarbonate at $1 \%$ of $\mathrm{DMI}$.

${ }^{3} \mathrm{C}=$ carbohydrate type effect $(\mathrm{F}$ and $\mathrm{F}+\mathrm{b}$ vs. $\mathrm{S}$ and $\mathrm{S}+\mathrm{b}) ; \mathrm{b}=$ bicarbonate supplementation effect $(\mathrm{F}$ and $\mathrm{S}$ vs. $\mathrm{F}+\mathrm{b}$ and $\mathrm{S}+\mathrm{b})$, and their interaction $(\mathrm{C} \times \mathrm{b})$

${ }^{4}$ Coelution with cis-14 C18:1.

${ }^{5}$ Coelution with C19:0.

${ }^{6}$ Coelution with trans-10 C19:1.

${ }^{7}$ Coelution with trans-10,cis-12 CLA and trans-9,cis-11 CLA.

${ }^{8}$ Coelution with trans-8, cis-10 CLA.

pH (Guyader et al., 2014), which may have impaired methanogen activity when $\mathrm{pH}$ is less than 6.0 (Van Kessel and Russell, 1996).

Effect of Bicarbonate Addition. To the best of our knowledge, the effect of dietary buffer addition on $\mathrm{CH}_{4}$ production in ruminants has poorly been studied. Our experiment showed that the addition of $1 \%$ bicarbonate had no effect on methanogenesis in dairy cows, regardless of the type of carbohydrate in diets based on grass silage, which is in agreement with Hellwing et al. (2012). Indeed, these authors reported no effect of $0.95 \%$ bicarbonate addition to a grass-clover silagebased diet rich in molasses. Furthermore, the addition of bicarbonate to diets did not influence nutrient digestibility, which confirms previous data in dairy cows fed a diet based on alfalfa and corn silage supplemented with $0.8 \%$ bicarbonate (Pereira and Armentano, 2000). Meschy et al. (2004) found by a meta-analysis approach (42 diets, 40 studies) that adding buffer at concentrations ranging from 0.5 to $2.5 \%$ of DMI had no effect on DM digestibility, but improved fiber digestibility.

Rumen $\mathrm{pH}$ measured thanks to commercial sensors positioned permanently in the reticulum of animals, could explain the relative high minimum $\mathrm{pH}$ values reported in our study whatever the diet. Reticulum $\mathrm{pH}$ has been reported to be higher than in the ventral and dorsal sacs of the rumen of cows fed diets of hay or mixed with $60 \%$ barley (Martin et al., 1999). As expected, bicarbonate addition acted as a rumen digestive regulator by increasing rumen $\mathrm{pH}$ (on average +0.14 units for mean $\mathrm{pH}$ and +0.06 units for minimum $\mathrm{pH}$ ). Meschy et al. (2004) observed a similar effect of 
bicarbonate addition on the mean rumen $\mathrm{pH}$, but to a lesser extent $(+0.07$ units for $\mathrm{pH}$ mean per $\%$ added buffer). Other rumen characteristics (VFA and protozoa) measured before the morning feeding were unaffected by addition of bicarbonate (only C3 proportions and ratios were slightly modified) regardless of the type of carbohydrates in diets. This was consistent with the absence of effect of bicarbonate addition on methanogenesis and on nutrient digestibility whatever the diet.

\section{Milk Fatty Acid Composition}

Effect of Carbohydrate Type. We reported that short- and medium-chain FA (C6:0, C8:0, C12:0, C14:0, and $\mathrm{C} 16: 0$ ), as well as the sum of SFA, were enhanced in milk fat from dairy cows fed starch-rich diets. As described in a review paper (Kalač and Samkova, 2010), high starch intake is associated with more milk SFA arising from a great level of de novo mammary synthesis. The milk $\mathrm{C} 4: 0$ concentration was reduced with cows fed the starch-rich diets, and this could be explained by the reduced numerical plasma $\mathrm{C} 2$ concentration, as well as the reduced rumen $\mathrm{C} 4$ concentration because $\mathrm{C} 2$ and C4 are precursors of de novo FA synthesis (Chilliard et al., 2007). Another explanation concerning the specific variation of $\mathrm{C} 4: 0$ compared with other short-chain $\mathrm{FA}$ could be due to the fact that this FA is synthesized in part by non-malonyl CoA mechanisms (not involving acetyl-CoA carboxylase; Chilliard et al., 2000).

Cows fed the starch-rich diets produced milk fat with greater $\mathrm{C} 15: 0$ and $\mathrm{C} 17: 0$ concentrations than fiberrich diets. Our results are in agreement with those of Vlaeminck et al. (2006) and Cabrita et al. (2007) who reported a positive relationship between odd-chain FA (C15:0 and C17:0) and dietary starch content. The increased milk concentration of C15:0 and 17:0 with more degradable dietary carbohydrate (i.e., starch-rich diets) could be due to a greater population of amylolytic bacteria, which produce and contain relatively large concentrations of C15:0 and C17:0 (Minato et al., 1988). A lower milk anteiso C15:0 concentration was found with cows fed starch-rich diets, which agrees with previous data on cows fed concentrate rich in corn grain compared with concentrate rich in citrus pulp (Cabrita et al., 2007).

Cows fed the starch-rich diets had less milk concentrations of total CLA, several major isomers of CLA, and C18:0. Our results suggest that RBH was reduced when cows received starch-rich diets. The lesser C18:2 n-6 and C18:3 n-3 intakes, due to the limited DMI in starch-rich diets, may explain the reduced RBH because these $2 \mathrm{FA}$ are the main precursors of RBH. Moreover, the lower minimum $\mathrm{pH}$ in the rumen observed with starch-rich diets could have modified the RBH in cows fed the starch-rich diets in comparison to fiber-rich diets, by increasing the milk trans-10 C18:1 concentration, leading only to a shift from trans-11 to trans-10 C18:1 for the $\mathrm{S}+\mathrm{b}$ diet, as shown by Bauman and Griinari (2003). In our study, it seems that the RBH pathway from C18:2 n-6 to C18:0, including the intermediates as trans-10,trans-12 and trans-8,cis-10 CLA, and trans-10 C18:1, has been favored for starch-rich diets.

Effect of Bicarbonate Addition. Bicarbonate addition decreased the concentration of some RBH intermediates, whereas we observed a greater concentration of the sum of CLA and cis-9,trans-11 CLA. These variations in milk FA composition suggest modifications in $\mathrm{RBH}$ pathways with bicarbonate addition, favoring the production of cis-9,trans-11 CLA. In contrast, Cabrita et al. (2009) observed a decrease in almost all $\mathrm{RBH}$ intermediate concentrations and a greater $\mathrm{C} 18: 0$ concentration, suggesting a more complete RBH with dietary buffer addition. Kennelly et al. (1999) observed a decrease in trans-10 C18:1 when buffer was added to a diet based on 75:25 concentrate-to-forage ratio. These authors suggested that the mechanism by which dietary buffers promote the completeness of $\mathrm{RBH}$ is due to an increase in rumen $\mathrm{pH}$, which modifies bacterial activity. In our study, buffer addition stabilized the rumen $\mathrm{pH}$, as hypothesized, and could have increased bacterial activity or number involved in the production of cis-9,trans-11 CLA. We observed a greater content of some trans FA, which was not expected at first. Further studies are needed to improve understanding of the mechanism by which dietary buffers modify RBH.

\section{CONCLUSIONS}

This study shows that for a 50:50 forage:concentrate ratio in grass silage-based diets, the dietary carbohydrate type had an effect on $\mathrm{CH}_{4}$ emissions in dairy cows as expected, but not on milk yield or on fat- or protein-corrected milk yield. Replacement of fiber by starch in diets decreased the energetic loss as $\mathrm{CH}_{4}$ emissions without improving feed efficiency of diets. The decrease in rumen protozoa number and the shift in rumen fermentation toward propionate for cows fed the starch-rich diets may be the main factors for reduced methanogenesis. Furthermore, starch-rich diets increased milk saturated short- and medium-chain FA and decreased the completeness of the biohydrogenation pathways of PUFA in the rumen, resulting in greater CLA content than in fiber-rich diet. The addition of $1 \%$ bicarbonate to diets induced rumen environment changes, through the increase of $\mathrm{pH}$ in starch-rich diets. Furthermore, no effects on $\mathrm{CH}_{4}$ emissions or nutrient digestibility were observed with bicarbonate addition, regardless of the type of carbohydrate in diets. Milk FA 
composition was slightly different between diets with or without bicarbonate, but bicarbonate addition did not prevent trans FA increase in milk as hypothesized. Reducing $\mathrm{CH}_{4}$ emissions in dairy cows fed starch-rich diets based on grass silage help to limit the negative environmental effect of ruminant livestock. However, milk nutritional value was depressed as saturated milk FA were present at greater concentration with starchrich diets than with fiber-rich diets.

\section{ACKNOWLEDGMENTS}

This experiment is part of a large collaborative project led by INRA with grant funding from a consortium of 11 institutes and private companies: Adisseo France SAS (Antony, France), Agrial (Caen, France), APIS-GENE (Paris, France), Deltavit (Janzé, France), DSM Nutritional Products AG (Kaiseraugst, Switzerland), Institut de l'Elevage (Paris, France), Lallemand (Blagnac, France), Moy Park Beef Orléans (Fleury-lesAubrais, France), Neovia (Saint-Nolff, France), Techna France Nutrition (Couëron, France), and Valorex (Combourtillé, France). This project aims to reduce enteric methane emissions via nutritional strategies. Animals were managed in the experimental facilities of the Experimental Unit Herbipôle (INRA, Herbipôle, Saint-Genès-Champanelle, France). The authors especially thank L. Mouly, V. Tate, S. Rudel, and D. Roux (INRA, Herbipôle, Saint-Genès-Champanelle, France) for animal care and feeding; E. Tixier, C. Delavaud, D. Bany, M. Tourret, I. Constant, L. Genestoux, and D. Graviou for laboratory analyses; and C. Lascoux and M. Silberberg for their help in obtaining and analyzing data (INRA, UMR Herbivores, Saint-Genès-Champanelle, France).

\section{REFERENCES}

AOAC International. 2005. Official Methods of Analysis. 18th ed. AOAC Int., Arlington, VA.

Bannink, A., J. Kogut, J. Dijkstra, J. France, E. Kebreab, A. M. Van Vuuren, and S. Tamminga. 2006. Estimation of the stoichiometry of volatile fatty acid production in the rumen of lactating cows. J. Theor. Biol. 238:36-51.

Bauman, D. E., and J. M. Griinari. 2003. Nutritional regulation of milk fat synthesis. Annu. Rev. Nutr. 23:203-227.

Benchaar, C., C. Pomar, and J. Chiquette. 2001. Evaluation of dietary strategies to reduce methane production in ruminants: A modelling approach. Can. J. Anim. Sci. 81:563-574.

Brashear, A., and G. A. Cook. 1983. A spectrophotometric, enzymatic assay for d-3-hydroxybutyrate that is not dependent on hydrazine. Anal. Biochem. 131:478-482.

Cabrita, A. R. J., R. J. B. Bessa, S. P. Alves, R. J. Dewhurst, and A. J. M. Fonseca. 2007. Effects of dietary protein and starch on intake, milk production, and milk fatty acid profiles of dairy cows fed cows fed corn silage-based diet. J. Dairy Sci. 90:1429-1439.

Cabrita, A. R. J., J. M. P. Vale, R. J. B. Bessa, R. J. Dewhurst, and A. J. M. Fonseca. 2009. Effects of dietary starch source and buf- fers on milk responses and rumen fatty acid biohydrogenation in dairy cows fed maize silage-based diets. Anim. Feed Sci. Technol. 152:267-277.

Chilliard, Y., A. Ferlay, R. M. Mansbridge, and M. Doreau. 2000. Ruminant milk fat plasticity: nutritional control or saturated, polyunsaturated, trans and conjugated fatty acids. Ann. Zootech. 49:181-205.

Chilliard, Y., F. Glasser, F. Enjalabert, A. Ferlay, F. Bocquier, and P. Schmidely. 2007. Données récentes sur les effets de l'alimentation sur la composition des acides gras du lait de vache, chèvre et brebis. Renc. Rech. Ruminants. 14:321-328.

Faisant, N., V. Plachot, F. Kozlowski, M. P. Pacouret, P. Colonna, and M. Champ. 1995. Resistant starch determination adapted to products containing high level of resistant starch. Sci. Alim. 15:83-89.

Ferlay, A., M. Doreau, C. Martin, and Y. Chilliard. 2013. Effect of incremental amounts of extruded linseed on the milk fatty acid composition of dairy cows receiving hay or corn silage. J. Dairy Sci. 96:6577-6595.

Gerber, P., T. Vellinga, C. Opio, and H. Steinfeld. 2011. Productivity gains and greenhouse gas emissions intensity in dairy systems. Livest. Sci. 139:100-108.

Gerber, P. J., H. Steinfeld, B. Henderson, A. Mottet, C. Opio, J. Dijkman, A. Falcucci, and G. Tempio. 2013. Tackling Climate Change through Livestock: A Global Assessment of Emissions and Mitigation Opportunities. Food and Agriculture Organization of the United Nations (FAO), Rome, Italy.

Guyader, J., M. Doreau, D. P. Morgavi, C. Gérard, C. Loncke, and C. Martin. 2016. Long-term effect of linseed plus nitrate fed to dairy cows on enteric methane emission and nitrate and nitrite residuals in milk. Animal 10:1173-1181.

Guyader, J., M. Eugene, B. Meunier, M. Doreau, D. P. Morgavi, M. Silberberg, Y. Rochette, C. Gérard, C. Loncke, and C. Martin. 2015. Additive methane-mitigating effect between linseed oil and nitrate fed to cattle. J. Anim. Sci. 93:3564-3577.

Guyader, J., M. Eugène, P. Nozière, D. P. Morgavi, M. Doreau, and C. Martin. 2014. Influence of rumen protozoa on methane emissions in ruminants: A meta-analysis approach. Animal 8:1816-1825.

Hassanat, F., R. Gervais, C. Julien, D. I. Masse, A. Lettat, P. Y. Chouinard, H. V. Petit, and C. Benchaar. 2013. Replacing alfalfa silage with corn silage in dairy cow diets: Effects on enteric methane production, ruminal fermentation, digestion, $\mathrm{N}$ balance, and milk production. J. Dairy Sci. 96:4553-4567.

Hellwing, A. L. F., M. Brask, P. Lund, and M. R. Weisbjerg. 2012. Effect of carbohydrate source and rumen $\mathrm{pH}$ on enteric methane from dairy cows. Pages 206-209 in Emissions of Gas and Dust from Livestock. M. Hassouna and N. Guingand, ed. INRA, Rennes, France, and IFIP, Le Rheu, France.

Hindrichsen, I. K., H. R. Wettstein, A. Machmüller, B. Jorg, and M. Kreuzer. 2005. Effect of the carbohydrate composition of feed concentrates on methane emission from dairy cows and their slurry. Environ. Monit. Assess. 107:329-350.

INRA (Institut National de la Recherche Agronomique). 2007. Alimentation des bovins ovins et caprins. Besoins des animaux - Valeurs des aliments - Tables INRA 2007. Editions Quae, Versailles, Paris, France.

Johnson, K. A., and D. E. Johnson. 1995. Methane emissions from cattle. J. Anim. Sci. 73:2483-2492.

Kalač, P., and E. Samkova. 2010. The effects of feeding various forages on fatty acid composition of bovine milk fat: A review. Czech J. Anim. Sci. 55:521-537.

Kennelly, J. J., B. Robinson, and G. R. Khorasani. 1999. Influence of carbohydrate source and buffer on rumen fermentation characteristics, milk yield, and milk composition in early-lactation Holstein cows. J. Dairy Sci. 82:2486-2496.

Krause, K. M., and G. R. Oetzel. 2006. Understanding and preventing subacute ruminal acidosis in dairy herds: A review. Anim. Feed Sci. Technol. 126:215-236.

Lerch, S., A. Ferlay, K. J. Shingfield, B. Martin, D. Pomiès, and Y. Chilliard. 2012. Rapseed or linseed supplements in grass-based diets: Effects on milk fatty acid composition of Holstein cows over two consecutive lactations. J. Dairy Sci. 95:5221-5241. 
Martin, C., E. Devillard, and B. Michalet-Doreau. 1999. Influence of sampling site on concentration and carbohydrate-degrading enzyme activities of protozoa and bacteria in the rumen. J. Anim. Sci. 77:979-987.

Martin, C., D. P. Morgavi, and M. Doreau. 2010. Methane mitigation in ruminants: From microbe to the farm scale. Animal 4:351-365.

Meschy, F., D. Bravo, and D. Sauvant. 2004. Analyse quantitative des réponses des vaches laitières à l'apport de substance tampon. INRA Prod. Anim. 17:11-18.

Minato, H., S. Ishibashi, and T. Hamaoka. 1988. Cellular fatty acid and sugar composition of representative strains of rumen bacteria. J. Gen. Appl. Microbiol. 34:303-319.

Moe, P. W., and H. F. Tyrrell. 1979. Methane production in dairy cows. J. Dairy Sci. 62:1583-1586.

Morgavi, D. P., J. P. Jouany, and C. Martin. 2008. Changes in methane emission and rumen fermentation parameters induced by refaunation in sheep. Anim. Prod. Sci. 48:69-72.

Morgavi, D. P., C. Martin, J. P. Jouany, and M. J. Ranilla. 2012. Rumen protozoa and methanogenesis: Not a simple cause-effect relationship. Br. J. Nutr. 107:388-397.

Pereira, M. N., and L. E. Armentano. 2000. Partial replacement of forage with nonforage fiber sources in lactating cow diets. II. Digestion and rumen function. J. Dairy Sci. 83:2876-2887.

Pinares-Patiño, C. S., C. Hunt, R. Martin, J. West, P. Lovejoy, and G. Waghorn. 2012. Chapter 1: New Zealand ruminant methane measurement centre, AgResearch, Palmerston North. Pages 9-28 in Technical Manual on Respiration Chamber Designs. C. S. Pinares Patino and G. Waghorn, ed. Ministry of Agriculture and Forestry, Wellington, New Zealand.
Pirondini, M., S. Colombini, M. Mele, L. Malagutti, L. Rapetti, G. Galassi, and G. M. Crovetto. 2015. Effect of dietary starch concentration and fish oil supplementation on milk yield and composition, diet digestibility, and methane emissions in lactating dairy cows. J. Dairy Sci. 98:357-372

Shen, J. S., Z. Chai, L. J. Song, J. X. Liu, and Y. M. Wu. 2012. Insertion depth of oral stomach tubes may affect the fermentation parameters of ruminal fluid collected in dairy cows. J. Dairy Sci. 95:5978-5984.

Shingfield, K. J., Y. Chilliard, V. Toivonen, P. Kairenius, and D. I. Givens. 2008. Trans fatty acids and bioactive lipids in ruminant milk. Adv. Exp. Med. Biol. 606:3-65.

Solorzano, L. C., L. E. Armentano, R. R. Grummer, and M. R. Dentine. 1989. Effects of sodium bicarbonate and sodium sesquicarbonate on lactating Holstein cows. J. Dairy Sci. 72:453-461.

Sukhija, P. S., and D. L. Palmquist. 1988. Rapid method for determination for total fatty acid contend composition of feedstuffs and feces. J. Agric. Food Chem. 36:1202-1206.

Van Kessel, J. A. S., and J. B. Russell. 1996. The effect of pH on ruminal methanogenesis. FEMS Microbiol. Ecol. 20:205-210.

Van Soest, P. J., J. B. Robertson, and B. A. Lewis. 1991. Methods for dietary fiber, neutral detergent fiber, and nonstarch polysaccharides in relation to animal nutrition. J. Dairy Sci. 74:3583-3597.

Vlaeminck, B., V. Fievez, A. R. J. Cabrita, A. J. M. Fonseca, and R. J. Dewhurst. 2006. Factors affecting odd- and branched-chain fatty acids in milk: A review. Anim. Feed Sci. Technol. 131:389-417.

Williams, A. G., and G. S. Coleman. 1992. The rumen protozoa. Springer-Verlag, London, UK. 